\title{
Transformational leadership and organizational citizenship behavior: Modeling emotional intelligence as mediator
}

\author{
Nauman MAJEED \\ Faculty of Business \& Accountancy, University of Malaya, Kuala Lumpur, Malaysia \\ majeed.nauman@gmail.com \\ T. RAMAYAH \\ School of Management, Universiti Sains Malaysia, Penang, Malaysia \\ Norizah MUSTAMIL \\ Faculty of Business \& Accountancy, University of Malaya, Kuala Lumpur, Malaysia \\ Mohammad NAZRI \\ Faculty of Business \& Accountancy, University of Malaya, Kuala Lumpur, Malaysia

\section{Samia JAMSHED} \\ Faculty of Business \& Accountancy, University of Malaya, Kuala Lumpur, Malaysia
}

\begin{abstract}
Leadership and organizational citizenship behavior (OCB) stayed at pinnacle in the arena of organizational behavior research since decades and has attained significant consideration of scholars pursuing to define multifaceted dynamics of leadership and their influence on follower's behavior at work. The voluntary behavior of Organizational citizenship improves organizational effectiveness, and it goes beyond formal job duties. This study attempts to explore the association amongst transformational leadership and organizational citizenship behavior of teachers in public sector higher education institutions in Pakistan. Study of organizational citizenship behavior in educational organizations and academicians is of high value that definitely requires attention. This study examines the direct and indirect influence of transformational leadership through exploring the mediating role of emotional intelligence. The model was tested by employing structural equation modelling technique on survey responses collected from academicians. Results from 220 responses indicated that relationship between transformational leadership and Organizational Citizenship Behavior is statistically significant where Emotional Intelligence plays an important role as a mediator. The results support and add to the positive effects of transformational leadership style interconnected with extra role behavior at work making it more meaningful. The findings make a significant contribution to leadership and organizational behavior literature in higher education sector and propose that organizations should implement practices that help in enhancing the level of organizational citizenship behavior in organizations.
\end{abstract}

Keywords: transformational leadership, emotional intelligence, organizational citizenship behavior, mediation.

Please cite the article as follows: Majeed, N., Ramaya, T., Mustamil, N., Nazri,M. and Jamshed, S. (2017), "Transformational Leadership and Organizational Citizenship Behavior: Modeling Emotional Intelligence as Mediator", Management and Marketing. Challenges for the Knowledge Society, Vol. 12, No. 4, pp. 571-590. DOI: 10.1515/mmcks-2017-0034.

\section{Introduction}

In fast pace competitive environment, public as well as private sector organizations of Pakistan are facing dilemma of employee citizenship behaviors, motivation, job satisfaction and meaningfulness of workplaces (Ramlall, 2004). In the last two decades, 
Pakistan has displayed substantial growth in higher education sector. There are 177 universities and degree awarding institutions in Pakistan scattered across its atlas and the quantity is rising at a high pace. Amongst the 177 universities, 103 are from public sector, whereas, remaining 74 have been established by the private sector. The government has also shown greater concern over the spending on university sector. A large number of initiatives have been taken to advance higher education. A significant development is noticeable, a lot needs to be taken care of especially in terms of teacher's commitment and their extra role behaviors. It is an undeniable reality that teachers in higher education play a central role in advancing and development of a society. With the increasing attention and reforms in this sector, teachers are not only responsible for teaching students, but they also have to carry out the duties of academic development and scientific research. Bearing in mind all these core functions performed, teachers are the central resource available to the universities as their performance and contributions are indispensable in achieving institutional goals. Leadership style of head of departments is an integral factor that can have a positive and profound impact on spirit de corps of the teachers.

Transformational leadership style was originally coined by Burns (1978) in his theory of transformational leadership that was advanced and refined by distinguished researchers like Bass (1985) and Avolio (1988) label transformational leader as farsighted, and able to accomplish change through grander assurance of his commands. Transformational leaders inculcate satisfaction among followers, which stimulates the individuals to perform extra role behaviors (Jung and Yoon, 2012). The literature review reveals that numerous revisions have been undertaken regarding the connection between transformational leadership and OCB (Bass, 1985; Burns, 1978; Cavazotte et al., 2012; Irshad and Hashmi, 2014; Lian and Tui, 2012; Ahmed, 2012). However, there are very few studies which assess the relationship between transformational leadership and OCB using mediation model. The current study proposes EI as mediator. Also, a very few research work has been done with regards to these variables in the education sector of Pakistan (Irshad and Hashmi, 2014; Ahmed, 2012). In constructing a framework connecting transformational leadership and OCB the authors also sketched on EI literature in order to recommend a mediating variable and its mechanism that has a high potential to benefit explaining a clear linkage between transformational leadership and OCB. From theoretical perspective, although various studies highlighted several antecedents of OCB but components of EI as antecedents is still lacking. In this regard, it is necessary to identify the theoretical contributions of OCB that connects to EI in workplace settings. However, rare studies so far have empirically confirmed the extent of EI that may have effects on the citizenship behavior. Therefore, there exists a significant research gap to identify the nature of relationship existing between emotional intelligence with OCB, particularly in the context of education sector of Pakistan. Theoretical opinions have advocated that EI makes a vital contribution to OCB and other organizational behaviors, but empirical proof of such an impact is deficient (Crossman, 2011).

The main purpose of this article is to provide empirical evidence that behaviors exhibited by transformational leaders can contribute positively to teachers' OCB and also to extend mainstream research on transformational leadership and its impact on OCB. Overall the key drive of this study is to offer empirical evidence that behaviors exhibited by transformational leaders can contribute positively to teachers' OCB. This study also aims to shape a model by theoretically and empirically linking transformational leadership, emotional intelligence and OCB in response to calls for 
additional work and wide-ranging, thoughtful understanding of a specific leadership methodology that transmits citizenship behaviors (Crossman, 2011).

\section{Literature review}

\section{Transformational leadership}

Transformational leadership has developed as relatively a central might in leadership research since last 20 years. Transformational leadership is frequently discussed as a "new paradigm" theory or "the new leadership" tactic (Bryman, 1992) .Transformational leaders set an example for the employees and motivate them to be creative and innovative. Researchers have identified that transformational leadership is pertinent to the academicians of higher education, i.e. transformational instructor leadership (Balwant, 2016). Bass (1985) in his book Leadership and Performance beyond Expectations has mentioned how transformational leaders inspire followers to achieve more than ordinary by making them realize their true potential. Transformational leadership emphasizes on a relationship-based performance which includes ethical practices, cooperation, healthy competition and unselfish approach towards goal attainment (Bass and Riggio, 2006).

In spite of the significance of impelling subordinates for leadership success, leaders in universities are usually not mindful of how powerful they can be, or obviously reflect their leadership style to inspire and stimulate employees, carry around additional determination and to escalate the performance of the universities. (Lo et al., 2010).

Transformational leadership is usually theorized as a set of interconnected behaviors that includes idealized influence, inspirational motivation, intellectual stimulation and individual consideration (Bass, 1985). By imparting idealized influence, leader turn as an example with a pledge to high principles and accomplishing the vision of a company. Through imparting inspirational motivation, leaders take into consideration emotional appeals to propose a convincing vision of the forthcoming events in future and stimulate subordinates to bind to a collective wisdom that speaks of a shared vision. Leaders use intellectual stimulation to inspire circles to raise their voices and challenge the status quo to resolve problems using innovative ideas. By imparting individual consideration, leaders personally attend to each and every individualized requirements of followers by paying attention, mentoring, and providing timely response. By way of applying such behaviors, transformational leaders inspire workforce to work extraordinary to attain superior goals (Podsakoff et al., 1990). Dinh et al. (2014) recently reviewed 752 articles published in 10 top academic journals during the period of 2000 to 2012 and found that transformational leadership is without doubt the highest researched field of leadership as compared to trait and behavioral theories of leadership.

\section{Emotional Intelligence}

The pervasive phenomena of emotional intelligence (EI) supports the idea of individual transformation likely to explain deviations in leadership and other behaviors. (Daus and Ashkanasy, 2005). EI is an emerging field in psychological and behavioral research. The concept of EI has come from "social intelligence" (Thorndike, 1920) which is defined as one's ability to handle people wisely in human relations. Since relations involve emotions and emotional expression are reflected in behaviors, scholars, in the early 1980s, began conceptualizing emotions in frame of EI. At first, the idea of EI was presented by Salovey and Mayer (1990) thereafter promoted by Boyatzis et al. (2000); 
who defined EI as the capability and skill to deal with emotions. Goleman (1998) wrote his renowned manuscript, "Emotional Intelligence: Why It can matter More Than IQ", which made this term ever popular. Jung and Yoon (2012) described that human relations are likely to be affected more by emotional influences than by lucid issues which, in turn, accentuated the significance of emotional intelligence in business. According to Martinez (1997), EI is a collection of non-cognitive skills, competencies and capabilities ultimately encourage individuals' capability to deal with demanding circumstances. According to Berman and West (2008), EI is competence to recognize own and feelings of others, consequently, facilitating own-self and others. According to Kaur et al. (2015) IQ is an intellectual construct which plays only management of data whereas much more deeper mechanisms is required by the organizations to handle interpersonal and intrapersonal charades. Saklofske et al. (2003) explained about investigation the psychometrical properties of EI exhibited a numeral unclear research matters which are required to be searched out. Different kind of theories about EI have been developed; one of which it is considered as ability model, second one is the trait model and third one is the mixed model (Goleman, 1998). Ability model belongs to cognitive skill of individual to manage reactions to emotions. Such abilities comprise observations, understanding and managing. In second trait model, it attempts to work out of the cognitive abilities but to some extent, this trait model is similar with the ability model as the cognition is one of the significant components of human attitude. Therefore, a clear cut wording is not possible whether it is an ability model or trait model. However, researchers tried to work out this problem with the help of different personality behavior (Petrides and Furnham, 2001). Mixed model tries to settle this misperception which exists in both ability and traits models. This misperception remained until Daniel Goleman theory of the fame (Goleman, 1998) in which he explained Emotional intelligence with the support of competencies and skills. The empathetic behavior was studied by Rebello (2011) in an educator's perspective and proved that teachers/ lecturers who were emotionally strong could perform better and more productive as they were empathetic towards others and well aware of their feelings and emotions. Further study by Balamohan et al. (2015) observed that those individuals, who were emotionally intelligent, were more successful and effective than others while managing their projects and even their subordinates and had strong influence on outputs of their projects. Therefore the significance of EI for an academician is irrefutable.

According to the University Kebangsaan Malaysia's (UKM Leads Research on EI, 2009) working environment with lot of stress and widespread workload are the main contributors to cause emotional labor and emotionally burdened behavior among the teaching profession. A research conducted in Malaysia on teachers of advanced learning institution discovered that academicians were not able to efficiently manage their emotions and possess deficient behaviors in regards to emotion regulation lacking while confronting with contemporaries (Rohana et al., 2009). The careers of teachers is known to be very crucial occupation (Ishak, Iskandar and Ramli, 2010), for academicians; EI might demonstrate to be vital personality attribute. EI is a key element as the triumph of a teacher in management of the circumstances and changes in education depends on it. By implementing emotional intelligence skills, teachers could improve their personal domain, better understand the social cues and effectively manage the work pressure (Nelson et al., 2006). Demographic variables such as age, gender, position title, educational and working experience may have positive association with emotional intelligence (Jorfi et al., 2011). 


\section{Organizational Citizenship Behavior}

Researchers, theorists and managers after much research realized that organizational success can only be reached when employees perform more than mere completion of required job task. Katz (1964) in his work on issues regarding employees' motivation within organization, invented terms "in role behavior" which were formally rewarded by organizational reward system and "extra role behavior" which were not rewarded by official reward system but were to enhance organizational effectiveness. The term "Organizational Citizenship Behavior" was coined by Bateman and Organ (1983) and put forth a sketch of informal behavior similar to Bernard (1938). Further defined OCB as discretionary behaviors not directly or explicitly recognized by the formal reward system, and that in the aggregate promotes the effective functioning of the organization" (Organ, 1988), he reconnoitered OCB more broadly and included three categories of behaviors courtesy, sportsmanship, and civic virtue.

Smith et al. (1983) were among the first who tried to explain the term "organizational citizenship behavior" in their study of nature and antecedents of OCB and proposed three different classes of OCB identified as "altruism" or "generalized compliance". Podsakoff et al. (2000) later based his seven themes of OCB on this study. Organ (1990) wrote an article by the name of "The motivational basis of organizational citizenship behavior" in which he reviewed the theoretical framework and explored altruism into dimension such as helping behavior, conscientiousness, adherence to attendance, work time and organizational rules. OCB is essential in the education system to promote the inclusive range of behaviors required to achieve goals. The employees OCB is becoming progressively vital in organizations in era of downsizing, economizing, and in reaction to the economic pressures of the past decade (Lo and Ramayah, 2009). Later, Podsakoff et al. (2000) acknowledged thirty different possible types of OCB and argued that conceptual overlap reduces them to only seven. Namely 1) helping behavior 2) sportsmanship 3) organizational loyalty 4) organizational compliance 5) individual initiative 6) civic virtue and 7) self-development. Conceptually, helping behavior has two parts 1) voluntary helping others 2) averting the happening of work associated problems.

Organ (1990) defined sportsmanship as "a willingness to tolerate the inevitable inconveniences and impositions of work without complaining". OCB historically has been explored in two streams of research as it is not a uni-dimensional concept 1) OCB and group 2) OCB and individual and recently team has been added to the league. Williams and Anderson (1991) first described the two factors 1) OCBI - the behaviors that directly benefit individual and 2) OCBO behaviors that benefit the organization. Their evidence suggests the two factors can be distinguished from in-role performance and may be related to other variables differentially. Research identifies antecedents of OCB as clarity of role, leadership, organizational justice (Ehrhart, 2004) organizational commitment, and individual traits (Chahal and Mehta 2010; Emami, Alizadeh, Nazari \& Darvishi, 2012) and is influenced by demographic factor, personality factors and organizational climate (Suresh and Venkatammal 2010).

\section{Relationships among the constructs}

Paine and Organ (2000) describe that leaders could play an important part in boosting OCB of the employees. According to Bryant (2003), transformational leaders develop an environment which is favorable to creation, sharing and exploration of knowledge. Through the traits of inspirational motivation, individualized attention, transformational leaders develop willingness in employees to exhibit citizenship 
behaviors. Transformational leaders heighten the citizenship behavior of followers through inspiring and motivating them to do extra effort. In a study by Choudhary, Kumar and Philip (2016) on effects of transformational leadership on followers OCB. A data on sample comprised of 142 teaching professionals working in China, India and Australia was collected. The findings revealed that significant association between transformational leadership and OCB in China and Australia but partially in India.

OCB and EI have become widely accepted notions and are particularly essential parts for individual performance (Rotundo and Sackett, 2002). Emotional intelligence as such has an exceptional potential to enhance human emotional understanding and cognitive aspects and the ambiance in which an individual's work is more likely to affect the OCB of employees which may be an impartial behavior of senior-level employees towards their subordinates to elevate their citizenship behavior (Organ, 1990). With regard to EI, Modassir and Singh (2008) have viewed that the leaders significantly correlated to the OCB of employees wherein the dimensions of altruism, conscientiousness and civic virtue were found to be related to EI and can predict EI of leaders as well. Similarly, Cavazotte et al. (2012) observed an association between altruism of OCB and EI whereas its dimensions; i.e. self-awareness, self-motivation and social skills have a colossal effect on personal citizenship behavior and these are the top forecasters of OCB (Naghdi and Shatalebi, 2013).

Sivanathan and Fekken (2002) analyzed that a huge number of followers perceived their leaders with high EI are real, influential and creative. These findings provide theoretical and empirical evidence of association in between EI and Transformational leadership. Later, they concluded that high EI leads to the improved behaviors pertaining to transformational leadership. Barling et al. (2000) emphasized that EI is relevant to three aspects of transformational leadership, idealized influence, inspirational motivation, and individualized consideration. The followers perceive individuals with higher EI are exhibiting extra leadership behaviors. Based on the findings about possible relationships among the variables, following hypotheses are formulated.

\section{Hypotheses}

H1: Transformational leadership has significant positive relationship with OCB.

H2: Transformational leadership has significant positive relationship with emotional intelligence.

H3: Emotional intelligence has significant positive relationship with OCB.

H4: Emotional intelligence mediates the relationship between transformational leadership and $O C B$.

\section{Conceptual framework}

The theory of transformational leadership has stimulated number of research scholars in field of organizational leadership over the decades. The theory was presented by Burns in 1978, further advanced by Bass (1985) and others (Bass \& Avolio, 1994). The primary idea of TL theory explains that leader's competency lies in inspiring followers to accomplish far beyond the existing plan to accomplish (Avolio et al.,2004). The theory presented by Bass in 1985 was grounded on transactional and transformation leaders' classification by Burns (1978). Bass reinforced that transformational leaders inspires follower to perform far beyond the assigned tasks. This research is conducted based on the design of transformational leadership theory as shown in conceptual framework in figure 1. Earlier studies confirmed influence of transformational leadership on OCB 
(Koh et al., 1995; MacKenzie et al., 2001; Podsakoff et al., 1990). Based on the evidence and theory conceptual framework is established. The independent variable utilizes Bass and Avolio (1994) Transformational leadership four dimensional construction idealized influence, inspirational motivation, intellectual simulation, and individualized consideration. The dependent variable is OCB among teachers in higher education institutions of Pakistan. OCB is essential in the education system because educational institutions may not forecast the whole range of behaviors required to achieve goals. This study is designed to assess how OCB is associated to transformational leadership.The mediating variable is emotional intelligence that consists of four dimensions. This study is based on Mayer Salovey Trait model that describes EI as association between cognition and emotion, defining EI as the "ability to perceive emotions, to access and generate emotions so as to assist thought, to understand emotions and emotional knowledge, and to reflectively regulate emotions so as to promote emotional and intellectual growth." (Mayor and Salovey, 1997; which encompasses cognitive emotional abilities.

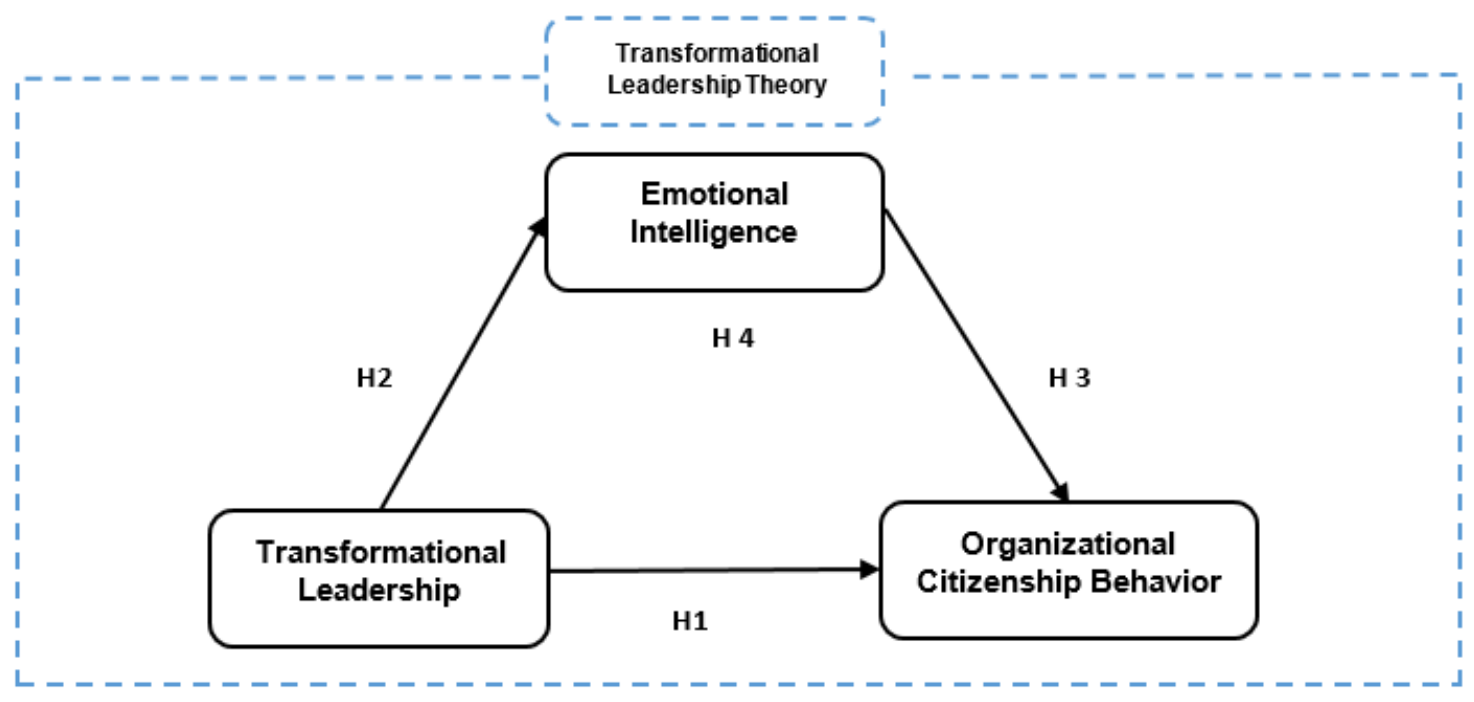

Figure 1. Conceptual framework

Source: Authors' own research.

\section{Methodology}

Considering the empirical nature of research study, the 'Quantitative Approach' (Positivism) is well-thought-out as the most suitable research methodology for attaining the results. The justification for picking quantitative approach is twofold. First, it best helps the aim of current research which is to explore the impact of Transformational leadership on OCB with proposed mediation. Secondly, to determine the direct impact of Transformational leadership on OCB, therefore associational approach was utilized for data analysis purpose. 


\section{Research instruments}

By utilizing structured questionnaire respondents were instructed to respond the items by using seven point Likert scale ranges from $1=$ "strongly disagree" to $7=$ "strongly agree".

Transformational Leadership: This construct was measured using Multifactor Leadership Questionnaire (MLQ) containing twenty items. This scale was given by Bass and Avolio (1995) with four dimensions and 20 items. Respondents were asked to rate the statements on a five-point Likert scale. Reliability of the scale was 0.88 .

Emotional Intelligence: This study used the scale developed by Wong and Law (2002) for assessing emotional intelligence. It is a 16-items scale consisting of four dimensions of self-emotion appraisal, others emotion appraisal, understanding others emotions and regulation of emotions. Scale reliability was 0.91 .

Organizational Citizenship Behavior (OCB): OCB was assessed using the 16-items scale given by Lee and Allen (2002) and was conceptualized in terms of OCBI (individual) and OCBO (organization). Reliability of the scale was 0.79 .

\section{Participants and procedure}

A pilot study was conducted to check the internal consistency of instrument. Fifty questionnaires were circulated among the permanent faculty members of 2 departments in a public sector university. Forty valid responses were received. The reliability measurements for transformational leadership, emotional intelligence and OCB $0.89,0.87$, and 0.83 .

Self-report questionnaires were distributed among 255 faculty members of four public sector universities of Pakistan in person. Each sealed packet contained the cover letter outlining the objectives of the research to help the respondents and to maintain the confidentiality of the responses received. Among the 255 questionnaires distributed by using convenience sampling design, 220 questionnaires were returned. All the questionnaires were complete, therefore considered as valid responses yielding a response rate of $86 \%$. Details of the response rate for each university are provided in table 1. During data preparation, respondents were identified with their universities and universities were coded as university 1-4 respectively.

\begin{tabular}{lccc}
\hline & Table 1. Questionnaires distributed and response rate \\
\hline Universities & $\begin{array}{c}\text { Questionnaires } \\
\text { distributed }\end{array}$ & $\begin{array}{c}\text { Questionnaires } \\
\text { received }\end{array}$ & Response Rate \\
\hline University 1 & 75 & 61 & $81 \%$ \\
University 2 & 60 & 51 & $85 \%$ \\
University 3 & 60 & 52 & $87 \%$ \\
University 4 & 60 & 56 & $93 \%$ \\
Total & 255 & 220 & $86 \%$ \\
\hline \multicolumn{4}{c}{ Source: Authors' own research results. }
\end{tabular}

Among the 220 self-report surveys returned, $60 \%$ respondents were males and $40 \%$ were females. The highest percentage of respondents (37\%) were aged between 31-40 years followed with the age breakdown as follows: $26-30$ (32\%), 40 \& above (20\%) and 18-25 (11\%). According to their level of education $81 \%$ of the participants had an M.Phil degree, 17\% held doctoral degree and 2\% held a master's degree. Under 
the category of position held $51 \%$ of participants were lecturer, $21 \%$ were senior lecturer, $19 \%$ were assistant professors, 5\% were associate professors and 5\% of participants held the position of professor. $37 \%$ of the respondents were associated with their organizations for 1-5 years, 34\% respondents had been working with the same organization for 6-10 years and 26\% participants had an organizational tenure of more than 11 years.

\begin{tabular}{lc}
\hline \multicolumn{2}{c}{ Table 2. Demographic characteristics } \\
\hline Variables & Total \\
Gender & \\
Male & $133(60)$ \\
Female & $87(40)$ \\
Age & \\
$18-25$ & $25(11)$ \\
$26-30$ & $70(32)$ \\
$31-40$ & $82(37)$ \\
40 \& above & $43(20)$ \\
Education Level & $4(2)$ \\
Master Degree & $178(81)$ \\
M.Phil Degree & $38(17)$ \\
Philosophy of doctor & \\
Position Held & $112(51)$ \\
Lecturer & $45(21)$ \\
Senior Lecturer & $41(19)$ \\
Assistant Professor & $11(5)$ \\
Associate Professor & $11(5)$ \\
Professor & \\
Organization Tenure & $82(37)$ \\
1-5 years & $75(34)$ \\
6-10 years & $57(26)$ \\
More than 11 years & * Data presented as (\%) \\
& Source: Authors' own research results. \\
\end{tabular}

\section{Data analysis}

The hypothesis explaining the relationship amongst constructs are empirically tested by employing Structural Equation Modelling - partial least square approach (SEM-PLS) using software Smart PLS M3 version 2.0 (Ringle et al., 2005).

\section{Outer model evaluation}

The connection amongst transformational leadership style of a leader as well as role of emotional intelligence on extra role behavior of academicians were tested using PLS approach. While assessing the outer model in PLS the initial step is to determine the accuracy of the theoretically defined constructs by ensuring the survey questionnaire has adequate level of reliability and validity by considering factor ladings, composite reliability (CR) and average variance extracted (AVE) of each construct.

\section{Construct validity}

To ensure the validation of constructs and indicators; loading of each item were assessed which indicated that loadings of all items measuring the respective construct is higher than 0.50 which is an acceptable level as recommended by Hair et al. (2011). The 
results revealed all values are positive and greater than the acceptable level, factor loading of all 52 items fall in the range of $0.51-0.83$ as reported in table 3 .

\section{Convergent validity}

While assessing the outer model, convergent validity is measured to assess the degree to which multiple items measure the same concept are related to each other. As suggested by Hair et al. (2011), convergent validity can be assessed by considering the values of factor loadings, CR and AVE. The values of composite reliability (CR) as reported in table 4 indicated that the CR values of all three variables lies in between 0.75 - 0.92 , which is an acceptable threshold value of 0.70 hence confirmed the reliability (Hair et al., 2011). Further average variance extracted (AVE) for each construct was examined. The value of AVE reveals the volume of variance in the observed variable accounted by the latent variable in relation to the measurement error (Ramayah et al., 2012). The recommended acceptable minimum value of AVE is 0.50 according to Barclay et al. (1995). Hence the results reveal that AVE's of all three values are in acceptable range i.e. $0.57-0.63$ confirming the condition of convergent validity.

\begin{tabular}{|c|c|c|c|c|}
\hline \multicolumn{5}{|c|}{ Table 3. Outer model } \\
\hline Constructs & Items & Loading & CR & AVE \\
\hline \multirow{20}{*}{ Transformational Leadership } & II1 & 0.53 & 0.85 & 0.57 \\
\hline & II2 & 0.54 & & \\
\hline & II3 & 0.51 & & \\
\hline & II 4 & 0.63 & & \\
\hline & II5 & 0.64 & & \\
\hline & IM1 & 0.53 & & \\
\hline & IM2 & 0.58 & & \\
\hline & IM3 & 0.61 & & \\
\hline & IM4 & 0.63 & & \\
\hline & IM5 & 0.58 & & \\
\hline & IS1 & 0.63 & & \\
\hline & IS2 & 0.51 & & \\
\hline & IS3 & 0.56 & & \\
\hline & IS4 & 0.51 & & \\
\hline & IS5 & 0.54 & & \\
\hline & IC1 & 0.51 & & \\
\hline & IC2 & 0.63 & & \\
\hline & IC3 & 0.59 & & \\
\hline & IC4 & 0.57 & & \\
\hline & IC5 & 0.58 & & \\
\hline \multirow[t]{9}{*}{ Emotional Intelligence } & SEA1 & 0.75 & 0.92 & 0.61 \\
\hline & SEA2 & 0.78 & & \\
\hline & SEA3 & 0.75 & & \\
\hline & SEA4 & 0.66 & & \\
\hline & OEA1 & 0.65 & & \\
\hline & OEA2 & 0.57 & & \\
\hline & OEA3 & 0.63 & & \\
\hline & OEA4 & 0.67 & & \\
\hline & ROE1 & 0.72 & & \\
\hline
\end{tabular}




\begin{tabular}{|c|c|c|c|c|}
\hline & ROE2 & 0.71 & & \\
\hline & ROE3 & 0.62 & & \\
\hline & ROE4 & 0.70 & & \\
\hline & UOE1 & 0.71 & & \\
\hline & UOE2 & 0.72 & & \\
\hline & UOE3 & 0.64 & & \\
\hline & UOE4 & 0.70 & & \\
\hline \multirow[t]{16}{*}{ Organizational Citizenship Behavior } & OCBI1 & 0.72 & 0.75 & 0.63 \\
\hline & OCBI2 & 0.60 & & \\
\hline & OCBI3 & 0.54 & & \\
\hline & OCBI4 & 0.56 & & \\
\hline & OCBI5 & 0.63 & & \\
\hline & OCBI6 & 0.54 & & \\
\hline & OCBI7 & 0.59 & & \\
\hline & OCBI8 & 0.81 & & \\
\hline & OCBO1 & 0.78 & & \\
\hline & OCBO2 & 0.79 & & \\
\hline & OCBO3 & 0.71 & & \\
\hline & OCBO 4 & 0.74 & & \\
\hline & OCBO5 & 0.73 & & \\
\hline & OCBO6 & 0.63 & & \\
\hline & OCBO7 & 0.57 & & \\
\hline & OCBO8 & 0.83 & & \\
\hline
\end{tabular}

Source: Authors' own research results.

\section{Discriminant validity}

The purpose of discriminant validity is to assess the degree of differentiation in between construct measuring the different concepts. Therefore discriminant validity could be measured via determining the correlations amongst the measures of different constructs. According to Fornell and Larcker (1981) criterion, the research model satisfies the condition of discriminant validity when the correlation among the construct have values below the square root values of AVE. The discriminant validity is good for this research model as reported in table 5 .

Table 4. Discriminant validity

\begin{tabular}{lccc}
\hline Constructs & EI & OCB & TL \\
Emotional Intelligence & $\mathbf{0 . 7 8}$ & & \\
Organizational Citizenship behavior & 0.54 & $\mathbf{0 . 7 9}$ & \\
Transformational leadership & 0.63 & 0.71 & $\mathbf{0 . 7 6}$ \\
\hline
\end{tabular}

The values in bold are the square root of variance shared between the latent variable and all other variables.

Source: Authors' own research results.

\section{Inner model evaluation}

The second stage in PLS-SEM is to assess the inner model. The purpose of inner model assessment is to test the hypothesized relationships for the work behaviors OCB. Specifically age, gender, organizational tenure, position held and education level were treated as control variables. Other latent variable includes transformational leadership 
and the mediator variable was emotional intelligence. Results of the analysis are presented in table 4. Initially the path coefficients of the relationships were examined and tested for being significant via looking at t-values by using bootstrapping technique. Moreover determination coefficients, value of R2 were examined to gauge the amount of variance in each construct as explained by the research model. The values of R2 and hypothesis tested are explained in table 5 . Transformational leadership significantly positively contributed to the prediction of OCB $(\beta=0.35, p<0.05)$ and emotional intelligence $(\beta=0.55$, $\mathrm{p}<0.05)$. Table 4 indicates that emotional intelligence explained a significant positive variation in OCB $(\beta=0.36, p<0.05)$ Thus, a positive relationship exists between emotional intelligence and OCB. The role of emotional intelligence as a mediator between transformational leadership-OCB interactions was tested using bootstrapping and analyzing path coefficients in PLS suggested by Hair et al (1998). Results indicated that when emotional intelligence was included in the transformational leadership-OCB interaction model, regression coefficient of transformational leadership was reduced from $(\mathrm{p}<0.05$ to $\beta=0.21, \mathrm{p}<0.05)$. In addition the variance accounted by the mediated model $\left(\mathrm{R}^{2}=0.19, \mathrm{p}<0.05\right)$ was more than the direct model $\left(\mathrm{R}^{2}=0.15, \mathrm{p}<0.05\right)$.This demonstrated that emotional intelligence mediated the relationship between transformational leadership and OCB.

\begin{tabular}{lcccccc}
\hline \multicolumn{7}{c}{ Table 5. Hypothesis testing } \\
\hline Relationships & $\begin{array}{c}\text { Standard } \\
\text { Beta }\end{array}$ & $\begin{array}{c}\text { Standard } \\
\text { error }\end{array}$ & T Statistics & P Values & Result & R2 \\
\hline H1: TL $\rightarrow$ OCB & 0.28 & 0.12 & 4.62 & $* 0.35$ & Supported & 0.15 \\
H2: TL $\rightarrow$ EI & 0.63 & 0.05 & 12.28 & $*^{*} 0.55$ & Supported & 0.19 \\
H3: EI $\rightarrow$ OCB & 0.16 & 0.08 & 2.12 & $* 0.36$ & Supported \\
H4: TLXEI $\rightarrow$ OCB & 0.08 & 0.03 & 2.52 & $* 0.05$ & Supported \\
\hline * Significant at 0.05 level of significance & & & \\
TL= Transformational Leadership; EI= Emotional Intelligence & & & \\
OCB=Organizational Citizenship behavior & & &
\end{tabular}

\section{Discussion}

An attempt is made in this study to test the direct effect of Transformational leadership on OCB and the mediating effect of emotional intelligence on the relationship between Transformational leadership and OCB. The outcomes of the study confirmed that transformational leadership style is positively associated to OCB of teachers. Based on the correlation analysis all hypotheses were supported. The present study enhanced the earlier proven relationship between transformational leadership and OCB by presenting the concept of emotional intelligence as a mediator. In addition, the relationship between emotional intelligence and OCB was found positive. Consequently, our outcomes go along with the assumption of quite a few researchers regarding the influence of the leadership style on OCB (Bass, 1985; Burns, 1978; Cavazotte et al., 2012; Irshad and Hashmi, 2014; Ahmed, 2012) and the mediating effect between these two variables through emotional intelligence. The study outcomes are reassuring of the posited relationships.

Adaptation of transformational leadership increases the employees' spirit at work and improves their willingness to perform extra work that is more meaningful. Particularly in the setting of educational institutions teachers' sense of belongingness towards the institution is of crucial importance. Therefore, our deductions also upkeep the transformational leadership theory, emphasizing the standing of reciprocation in social exchange. More precisely, this type of connection between the faculty head and 
teacher causes the teachers to devote in their work and offer to the organization above and beyond formal role expectations, thus articulating extra role behaviors. Further the connection of emotional intelligence and OCB postulates this point that in order to upsurge spirit at work and engaging employee more, emotional intelligence can play a significant role that can boost loyalty. Promoting emotional intelligence in organization offers a framework for increasing the level of OCB. The outcomes of current study is comparable to the result of the study of Anwar et al. (2017) testified that the emotional intelligence and its complete aspect had a significant relationship with OCB. Moreover, the result of the study of demonstrated that there was a noteworthy and constructive association between emotional intelligence OCB and emotional intelligence is one of the key determinant of OCB. The results of the study are also constant with hypothetical and empirical evidence (Tischler et al., 2002; Duchon and Plowman, 2005) signifying that when people catch sense in their doings and, in general, feel tangled in splendidly spiritual organizational environments, they act in higher involved and concerted manner, smear their complete potential to work and carry their entire selves to the organization. They consequently become more creative over the long run equated with workers in organizations wherever EI is overlooked or belittled. The study suggests that abandoning EI can lead employees producing less organizational citizenship behaviors, high turnover rate, more absenteeism, neglecting behaviors and inferior capacity to gratify customers (Meyer and Herscovitch, 2001), which in turn may lead to lesser organizational enactment. The results offered by this study marks few solid contributions. First general contribution is that we have established and verified a theoretical model that exceptionally incorporates Transformational leadership theory with emotional intelligence theory and OCB. Our results supports propositions by researchers that Transformational leadership addresses the underpinnings of OCB. Secondly our study makes a significant contribution to leadership, emotional intelligence and OCB literature by probing and endorsing emotional intelligence as a mediating instrument or mechanism through which transformational leadership eventually influences OCB. Our conclusions are also consistent with earlier research aiming to a positive association between Transformational leadership and EI. As Fry (2003) suggested that transformational leadership is expected to have its influence on employees sense of wholeness, an admiration of their inner lives that is nurtured by meaningful and invigorating job efforts which occurred in setting of community connected by a common purpose, profounder values and belongingness at work. This study has facilitated in building theoretical argument and established a link and connection between emotional intelligence and OCB. Rare researches have attempted to link a connection between emotional intelligence and OCB.

\section{Limitations}

A few limitations connected with this study that must be discussed. First, authors could not establish causality due to the nature of data being cross sectional. Future research employing a longitudinal approach needs to be considered for deeper insight into the subject and more definite conclusion about the causal effect between each variable. Further studies may also enhance the descriptive power of the model by accumulation of further mediating and moderating variables that more systematically clarify link between Transformational leadership and OCB.

The data gathered from 220 teachers working in four public sector universities. Therefore, results need to be validated with large sample size including private sector universities as well to enhance the generalizability. Moreover the data was collected by 
utilizing self-reported survey instrument that may be liable to few biases integral to such an approach. In spite of these limitations, the current study shows that transformational leadership and emotional intelligence provide auxiliary means to increase OCB of teachers in public sector. The self-reported data may lead to the limitations of common method variance and have the chance for over or under estimations that cannot be conclusively ruled out, hence further study should omit this biasness. Further empirical research can make significant contributions to the field of industrial and manufacturing sectors as well as can provide a comparative view between different gender and different age range sample.

Lastly, the results are based on Pakistan public sector employees of higher education institutions and may not be generalizable to other contexts. Using these contributors bounds the generalizability of the results to a greater population. Workforce from different cultures and characters should be studied to acquire thorough contrasts. However, studies of leadership are largely reliable across diverse national settings (Avolio et al., 2004).

\section{Recommendations for future research}

Irrespective of few limitations, the main objective of the study is accomplished. The key objective is to add to the leadership work by ascertaining associations between variables under its purview. This research has extended knowledge through which transformational leadership increases an employee level of OCB. This research adopted convenience sampling technique to achieve the research purposes. Random sampling is suggested for such studies in future which might enhance the results and address the issue of generalizability. Future research can focus on other mediating variables such as, employee engagement, workplace deviance, organizational culture and knowledge sharing behavior. Furthermore, given the subjective and extremely individual nature of the OCB concept, it would be perfect if multiple approaches of research to be employed in future to cross validate these methods, to include interviews from employees, supervisor valuations of employees, and other qualitative measures.

\section{Practical implications}

This study offers practical implications and empirical confirmation that transformational leadership is positively associated to OCB directly and indirectly through mediating mechanism of emotional intelligence. The results indicate that superiors must be vigilant about their actions as it stimuli employees' performance of extra role behaviors. Universities should offer official training to the head of departments to exercise transformational leadership behaviors which will in turn improve teachers' OCB. In addition, programs aimed at enhancing teachers emotional intelligence must be hosted in the campuses. These programs should include both supervisors and teachers. This will facilitate in improving the efficacy of such programs to incorporate the lessons learned during these programs. Besides, it is important to employ such research in diverse institutional environments, such as dissimilarities in for-profit versus non-profit organizations.

This unique theoretical model likewise has value added implication for University managers. TL and EI is important to encourage teachers to display loyalty and citizenship behaviors. Consequently managers ought to understand that in order to nurture OCB to increased level display of leadership style and emotional intelligence is crucial. It enables employees to engage themselves fully into their work thus reciprocating organization through extra role at work instead withholding effort on job. 
The university administrators/managers should understand that transformational leadership approach and high level of leader's emotional intelligence can engage the soul and lift the heart of employees.

Furthermore, the study provides imperative suggestions for practitioners. With reference to the hiring process, the researchers propose that organizations aim to advance and create a healthier organizational environment through OCB should place more importance on candidates selection who possess higher levels of emotional intelligence. Thus, appropriate tests should be conducted during the recruitment and selection process for finding potential candidates who hold ample traits of emotional intelligence. In addition emotional intelligence training can be an influential package that organizations should consider as reported by Sturm, Rosen, Allison, Miller and Levenson, (2006). Individuals after one year of emotional intelligence training, the participants who attended the training were found to possess increased and much higher levels of fellow feeling, tolerance, spiritual experience, patience and job satisfaction.

While this is a promising study that has provided an empirical support, however additional research is required to explore broad nature of the association amongst the constructs. In conclusion, the study uniquely synthesizes theories of Transformational leadership, Emotional Intelligence and OCB can further build and test the potential impact of Transformational leadership and Emotional intelligence on OCB. In consequence our hypothetical model that has received empirical backing and support sets the platform for supplementary research and progress in theory to understand how Transformational leadership can increase other organizational outcomes along with OCB.

\section{References}

Ahangar, R.G. (2009), "Building managers as transformational leaders in public sector banks", International Review of Business Research Papers, Vol. 5, No. 5, pp. 355364.

Ahmad, A.S.S. (2012), "Perceived transformational leadership style and organizational citizenship behavior: a case study of administrative staff of University of the Punjab", European Journal of Business and Management, Vol. 4, No. 21, pp. 150158.

Allen, T.D., Barnard, S., Rush, M.C. and Russell, J.E. (2000), "Ratings of organizational citizenship behavior: Does the source make a difference?", Human Resource Management Review, Vol. 10, No. 1, pp. 97-114.

Anwar, M.A. and Osman-Gani, A.M. (2015), "The effects of spiritual intelligence and its dimensions on organizational citizenship behaviour", Journal of Industrial Engineering and Management, Vol. 8, No. 4, p. 1162.

Anwar, M.A., Anwar, M.A., Osman-Gani, A.M., Osman-Gani, A.M., Fontaine, R., Fontaine, R., Rahman, M.S. and Rahman, M.S. (2017), "Assessing organizational citizenship behaviour through constructing emotional intelligence", Asia-Pacific Journal of Business Administration, Vol. 9, No. 2, pp. 105-117.

Avolio, B.J., Waldman, D.A. and Einstein, W.O. (1988), "Transformational leadership in a management game simulation: Impacting the bottom line", Group \& Organization Studies, Vol. 13, No. 1, pp. 59-80.

Avolio, B.J., Bass, B.M. and Zhu, F.W.W. (2004), Multifactor leadership questionnaire: manual and sampler set, Mind Garden Redwood City. 
Barclay, D., Higgins, C. and Thompson, R. (1995), "The partial least squares (PLS) approach to causal modeling: Personal computer adoption and use as an illustration", Technology studies, Vol. 2, No. 2, pp. 285-309.

Barling, J., Slater, F. and Kevin Kelloway, E. (2000), "Transformational leadership and emotional intelligence: An exploratory study",Leadership \& Organization Development Journal, Vol. 21, No. 3, pp. 157-161.

Barnard, C.I. (1938), The functions of the executive, Harvard University, Cambridge.

Bass, B.M. (1985), Leadership and performance beyond expectations. Collier Macmillan.

Bass, B.M. and Avolio, B.J. (1995), Multifactor leadership questionnaire: Manual leader form, rater, and scoring key for MLQ (Form 5x-Short), Mind Garden, Redwood City.

Bass, B.M. and Riggio, R.E. (2006), Transformational leadership, Psychology Press.

Bass, B.M. and Avolio, B.J. (1994). Improving organizational effectiveness through transformational leadership. Sage.

Bateman, T.S. and Organ, D.W. (1983), "Job satisfaction and the good soldier: The relationship between affect and employee 'citizenship'", Academy of Management Journal, Vol. 26, No. 4, pp. 587-595.

Balamohan, P., Tech, M. and Gomathi, S. (2015), "Emotional intelligence-Its importance and relationship with individual peformance, team-effectiveness, leadership and marketing effectiveness", Mediterranean Journal of Social Sciences, Vol. 6, No. 1, p. 120.

Balwant, P.T. (2016), "Transformational instructor-leadership in higher education teaching: a meta-analytic review and research agenda", Journal of Leadership Studies, Vol. 9, No. 4, pp. 20-42.

Berman, E.M. and West, J.P. (2008), "Managing emotional intelligence in US cities: A study of social skills among public managers", Public Administration Review, Vol. 68, No. 4, pp. 742-758.

Boyatzis, R.E., Goleman, D. and Rhee, K. (2000), "Clustering competence in emotional intelligence: Insights from the Emotional Competence Inventory (ECI)", Handbook of Emotional Intelligence, Vol. 99, No. 6, pp. 343-362.

Bryant, S.E. (2003), "The role of transformational and transactional leadership in creating, sharing and exploiting organizational knowledge", Journal of Leadership \& Organizational Studies, Vol. 9, No. 4, pp. 32-44.

Bryman, A. (1992), Charisma and leadership in organizations, Sage.

Burns, J.M. (1978), Leadership, Harper \& Row. New York.

Cavazotte, F., Moreno, V. and Hickmann, M. (2012), "Effects of leader intelligence, personality and emotional intelligence on transformational leadership and managerial performance", The Leadership Quarterly, Vol. 23, No. 3, pp. 443-455.

Chahal, H. and Mehta, S. (2010), "Antecedents and consequences of organisational citizenship behaviour (OCB): A conceptual framework in reference to health care sector", Journal of Services Research, Vol. 10, No. 2, p. 25.

Choudhary, N., Kumar, R. and Philip, P.J. (2016), "Effects of transformational leadership on follower's organizational citizenship behavior: The moderating role of culture", Prabandhan: Indian Journal of Management, Vol. 9, No. 7, pp. 23-35.

Crossman, J. (2011), "Environmental and spiritual leadership: Tracing the synergies from an organizational perspective", Journal of Business Ethics, Vol. 103, No. 4, pp. 553-565.

Daus, C.S. and Ashkanasy, N.M. (2005), "The case for the ability-based model of emotional intelligence in organizational behavior", Journal of Organizational behavior, Vol. 26, No. 4, pp. 453-466. 
Dinh, J.E., Lord, R.G., Gardner, W.L., Meuser, J.D., Liden, R.C. and Hu, J. (2014), "Leadership theory and research in the new millennium: Current theoretical trends and changing perspectives", The Leadership Quarterly, Vol. 25, No. 1, pp. 36-62.

Duchon, D. and Plowman, D.A. (2005), "Nurturing the spirit at work: Impact on work unit performance", The leadership quarterly, Vol. 16, No. 5, pp. 807-833.

Ehrhart, M.G. (2004), "Leadership and procedural justice climate as antecedents of unitlevel organizational citizenship behavior", Personnel Psychology, Vol. 57, No. 1, pp. 61-94.

Emami, M., Alizadeh, Z., Nazari, K. and Darvishi, S. (2012), "Antecedents and consequences of organisational citizenship behaviour (OCB)", Interdisciplinary Journal of Contemporary Research in Business, Vol. 3, No. 9.

Fornell, C. and Larcker, D.F. (1981), "Structural equation models with unobservable variables and measurement error: Algebra and statistics", Journal of Marketing Research, Vol. 18, No. 3, pp. 382-388.

Fry, L.W. (2003), "Toward a theory of spiritual leadership", The Leadership quarterly, Vol. 14, No. 6, pp. 693-727.

Gardner, L. and Stough, C. (2002), "Examining the relationship between leadership and emotional intelligence in senior level managers", Leadership \& Organization Development Journal, Vol. 23, No. 2, pp. 68-78.

Goleman, D. (1998), Working with emotional intelligence, Bantam.

Goleman, D., Boyatzis, R. and McKee, A. (2002), Primal leadership: Realizing the power of emotional intelligence, Macmillan.

Griffin, M.A., Neal, A. and Parker, S.K. (2007), "A new model of work role performance: Positive behavior in uncertain and interdependent contexts", Academy of Management Journal, Vol. 50, No. 2, pp. 327-347.

Hair, J.F., Sarstedt, M. and Ringle, C. (2011), "Partial least squares structural equation modeling: Indeed a silver bullet", Journal of Marketing Theory \& Practice, Vol. 18, No. 2.

Hans, A., Mubeen, S.A. and Al Rabani, R.S.S. (2013), "A study on emotional intelligence among teachers: a case study of private educational institutions in Muscat", International Journal of Application or Innovation in Engineering \& Management (IJAIEM), Vol. 2, No. 7, pp. 359-366.

Irshad, R. and Hashmi, M.S. (2014), "How transformational leadership is related to organizational citizenship behavior? The mediating role of emotional intelligence", Pakistan Journal of Commerce \& Social Sciences, Vol. 8, No. 2, pp. 413-425.

Ishak, N.M., Mustapha, R., Mahmud, Z. and Ariffin, S.R. (2006), "Emotional intelligence of Malaysian teachers: Implications on workplace productivity", International Journal of Vocational Education and Training, Vol. 14, No. 2, pp. 8-24.

Jacobs, R.L. and McClelland, D.C. (1994), "Moving up the corporate ladder: A longitudinal study of the leadership motive pattern and managerial success in women and men", Consulting Psychology Journal: Practice and Research, Vol. 46, No. 1, p. 32.

Jha, S. (2014), "Transformational leadership and psychological empowerment: Determinants of organizational citizenship behavior", South Asian Journal of Global Business Research, Vol. 3, No. 1, pp. 18-35.

Jordan, P.J. and Troth, A.C. (2004), "Managing emotions during team problem solving: Emotional intelligence and conflict resolution", Human Performance, Vol. 17, No. 2, pp. 195-218. 
Jorfi, H., Yaccob, H.F.B. and Shah, I.M. (2011), "The relationship between demographics variables, emotional intelligence, communication effectiveness, motivation, and job satisfaction", International Journal of Academic Research in Business and Social Sciences, Vol. 1, No. 1, pp. 35-58.

Jung, H.S. and Yoon, H.H. (2012), "The effects of emotional intelligence on counterproductive work behaviors and organizational citizen behaviors among food and beverage employees in a deluxe hotel", International Journal of Hospitality Management, Vol. 31, No. 2, pp. 369-378.

Katz, D. (1964), "The motivational basis of organizational behavior", Systems Research and Behavioral Science, Vol. 9, No. 2, pp. 131-146.

Kaur, D., Sambasivan, M. and Kumar, N. (2015), "Impact of emotional intelligence and spiritual intelligence on the caring behavior of nurses: a dimension-level exploratory study among public hospitals in Malaysia", Applied Nursing Research, Vol. 28, No. 4, pp. 293-298.

Koh, W.L., Steers, R.M. and Terborg, J.R. (1995), "The effects of transformational leadership on teacher attitudes and student performance in Singapore", Journal of Organizational Behavior, Vol. 16, No. 4, pp. 319-333.

Kumar, J.A. and Muniandy, B. (2012), "The influence of demographic profiles on emotional intelligence: A study on polytechnic lecturers in Malaysia", International Online Journal of Educational Sciences, Vol. 4, No. 1, pp. 62-70.

Lian, L.K. and Tui, L.G. (2012), "Leadership styles and organizational citizenship behavior: The mediating effect of subordinates' competence and downward influence tactics", The Journal of Applied Business and Economics, Vol. 13, No. 2, p. 59.

Lee, K. and Allen, N.J. (2002), "Organizational citizenship behavior and workplace deviance: the role of affect and cognitions", Journal of Applied Psychology, Vol. 87, No. 1, p. 131.

Lo, M.C. and Ramayah, T. (2009), "Dimensionality of organizational citizenship behavior (OCB) in a multicultural society: The case of Malaysia", International Business Research, Vol. 2, No. 1, p. 48.

Lo, M.C., Ramayah, T. and De Run, E.C. (2010), "Does transformational leadership style foster commitment to change? The case of higher education in Malaysia", Procedia-Social and Behavioral Sciences, Vol. 2, No. 2, pp. 5384-5388.

Masi, R.J. and Cooke, R.A. (2000), "Effects of transformational leadership on subordinate motivation, empowering norms, and organizational productivity", The International Journal of Organizational Analysis, Vol. 8, No. 1, pp. 16-47.

Mayer, J.D. (2010), "What is emotional intelligence", In: P. Salovey. \& D. Sluyter (Eds.), Emotional Development and Emotional Intelligence: Educational Implications, pp. 3-34.

Martinez-Pons, M. (1997), "The relation of emotional intelligence with selected areas of personal functioning", Imagination, Cognition and Personality, Vol. 17, No. 1, pp. 3-13.

Meyer, J.P. and Herscovitch, L. (2001), "Commitment in the workplace: Toward a general model", Human Resource Management Review, Vol. 11, No. 3, pp. 299326.

Modassir, A. and Singh, T. (2008), "Relationship of emotional intelligence with transformational leadership and organizational citizenship behavior", International Journal of Leadership Studies, Vol. 4, No. 1, pp. 3-21. 
Naghdi, M. and Shatalebi, B. (2013), "The predictability of the organizational citizenship behavior through emotional intelligence dimensions in personnel of Isfahan municipality", Kuwait Chapter of the Arabian Journal of Business and Management Review, Vol. 2, No. 5, p. 36.

Organ, D.W. (1988), Organizational citizenship behavior: The good soldier syndrome, Lexington Books/DC Heath and Com.

Organ, D.W. (1990), "The motivational basis of organizational citizenship behavior", Research in Organizational Behavior, Vol. 12, No. 1, pp. 43-72.

Organ, D.W., Podsakoff, P.M. and MacKenzie, S.B. (2005), Organizational citizenship behavior: Its nature, antecedents, and consequences, Sage Publications.

Paine, J.B. and Organ, D.W. (2000), "The cultural matrix of organizational citizenship behavior: Some preliminary conceptual and empirical observations", Human Resource Management Review, Vol. 10, No. 1, pp. 45-59.

Palmer, B., Walls, M., Burgess, Z. and Stough, C. (2001), "Emotional intelligence and effective leadership", Leadership \& Organization Development Journal, Vol. 22, No. 1, pp. 5-10.

Petrides, K.V. and Furnham, A. (2000), "On the dimensional structure of emotional intelligence", Personality and Individual Differences, Vol. 29, No. 2, pp. 313-320.

Petrides, K.V. and Furnham, A. (2001), "Trait emotional intelligence: Psychometric investigation with reference to established trait taxonomies", European Journal of Personality, Vol. 15, No. 6, pp. 425-448.

Podsakoff, P.M., MacKenzie, S.B., Moorman, R.H. and Fetter, R. (1990), "Transformational leader behaviors and their effects on followers' trust in leader, satisfaction, and organizational citizenship behaviors", The Leadership Quarterly, Vol. 1, No. 2, pp. 107-142.

Podsakoff, P.M., MacKenzie, S.B., Paine, J.B. and Bachrach, D.G. (2000), "Organizational citizenship behaviors: A critical review of the theoretical and empirical literature and suggestions for future research", Journal of Management, Vol. 26, No. 3, pp. 513-563.

Ramlall, S. (2004), "A review of employee motivation theories and their implications for employee retention within organizations", Journal of American Academy of Business, Vol. 5, No. 1/2, pp. 52-63.

Ramayah, T., Lee, J.W.C. and Lim, S. (2012), "Sustaining the environment through recycling: An empirical study", Journal of Environmental Management, Vol. 102, pp. 141-147.

Rebello, F.S. (2011), "Emotional intelligence and employee productivity: an educator's perspective", Faculty of Commerce and Management Studies, pp.1-6.

Ringle, C.M., Wende, S. and Will, A. (2005), SmartPLS 2.0. M3 (beta), University of Hamburg.

Rohana, N. and Kamaruzaman, J., Zanariah. AR (2009), "Emotional intelligence of malaysian academia towards work performance", International Education Studies, Vol. 2, No. 2, pp. 103-112.

Rotundo, M. and Sackett, P.R. (2002), "The relative importance of task, citizenship, and counterproductive performance to global ratings of job performance: a policycapturing approach", Journal of Applied Psychology, Vol. 87, No. 1, p. 66.

Saklofske, D.H., Austin, E.J. and Minski, P.S. (2003), "Factor structure and validity of a trait emotional intelligence measure", Personality and Individual Differences, Vol. 34, No. 4, pp. 707-721. 
Salovey, P. and Mayer, J.D. (1990), "Emotional intelligence", Imagination, Cognition and Personality, Vol. 9, No. 3, pp. 185-211.

Sivanathan, N. and Cynthia Fekken, G. (2002), "Emotional intelligence, moral reasoning and transformational leadership", Leadership \& Organization Development Journal, Vol. 23, No. 4, pp. 198-204.

Smith, C.A., Organ, D.W. and Near, J.P. (1983), "Organizational citizenship behavior: Its nature and antecedents", Journal of Applied Psychology, Vol. 68, No. 4, p. 653.

Sturm, V.E., Rosen, H.J., Allison, S., Miller, B.L. and Levenson, R.W. (2006), "Self-conscious emotion deficits in frontotemporal lobar degeneration", Brain, Vol. 129, No. 9, pp. 2508-2516.

Suresh, S. and Venkatammal, P. (2010), "Antecedents of organizational citizenship behaviour", Journal of the Indian Academy of Applied Psychology, Vol. 36, No. 2, pp. 276-286.

Thorndike, E.L. (1920), "Intelligence and its uses", Harper's Magazine.

Tischler, L., Biberman, J. and McKeage, R. (2002), "Linking emotional intelligence, spirituality and workplace performance: Definitions, models and ideas for research", Journal of Managerial Psychology, Vol. 17, No. 3, pp. 203-218.

Turner, L. (2004), "Emotional intelligence-our intangible asset? It's not just about being technically competent", Chartered Accountants Journal of New Zealand, Vol. 83, No. 3, pp. 29-31.

Wong, C.S. and Law, K.S. (2002), "The effects of leader and follower emotional intelligence on performance and attitude: An exploratory study", The Leadership Quarterly, Vol. 13, No. 3, pp. 243-274.

Williams, L.J. and Anderson, S.E. (1991), "Job satisfaction and organizational commitment as predictors of organizational citizenship and in-role behaviors", Journal of Management, Vol. 17, No. 3, pp. 601-617.

Yukl, G. (1989), "Managerial leadership: A review of theory and research", Journal of Management, Vol. 15, No. 2, pp. 251-289. 